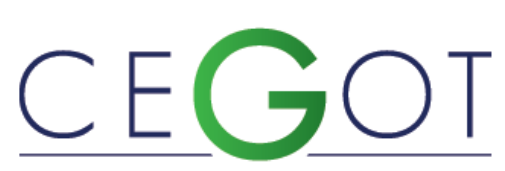

Centro de Estudos de Geografia e Ordenamento do Território
Geografia e Ordenamento do Território, Revista Eletrónica Centro de Estudos de Geografia e Ordenamento do Território http://cegot.org LOBÃO, MÁRIO

Instituto Federal do Acre (IFAC)

Rua Raimundo Malaquias - 20, Floresta Sul, 69.9912-338 Rio Branco/AC, Brasil

mario.lobao@ifac.edu.br

\title{
Amazônia rural brasileira: aspetos sociodemográficos
}

\section{Brazilian rural Amazon: sociodemographic aspects}

Referência: Lobão, Mário (2019). Amazônia rural brasileira: aspetos sociodemográficos. Revista de Geografia e Ordenamento do Território (GOT), n. ${ }^{\circ} 17$ (junho). Centro de Estudos de Geografia e Ordenamento do Território, p. 123-150, dx.doi.org/10.17127/got/2019.17.006

\section{RESUMO}

O objetivo é analisar, sociodemograficamente, o território rural da Amazônia brasileira. Foi utilizado uma abordagem qualitativa de cunho exploratório. Demograficamente, a sociedade rural amazônica ainda é bastante jovem. Quando essa população jovem atinge a idade de serem economicamente ativa, acabam migrando para centros urbanos. As mulheres são minoria e migram em maior intensidade que os homens. As condições sociais de moradia são precárias, principalmente com o abastecimento e acesso a água encanada, bem como com a falta de saneamento adequado.

Palavras-chave: Amazônia. Território Rural. Sociedade Amazônica. Demografia.

\section{ABSTRACT}

The objective is to analyze, sociodemographically, the rural territory of the Brazilian Amazon. Was used a qualitative exploratory approach. Demographically, the Amazonian rural society is still quite young. When this young population reaches the age of being economically active they end up migrating to urban centers. Women are a minority and migrate in greater intensity than men migrate. The social conditions of housing are precarious, mainly with the supply and access to running water, as well as the lack of adequate sanitation.

Keywords: Amazon. Rural Territory. Society. Demography. 


\section{Introdução}

A Amazônia brasileira ${ }^{1}$ é marcada por alguns principais movimentos histórico-sociais. 0 primeiro e segundo ciclo da borracha, datados do final do século XIX e início do século XX, bem como o movimento de exploração e ocupação a partir dos anos 1960, com os governos militares e, mais recentemente, com o avanço da fronteira agrícola marcaram esses principais fatos históricos na região. Foram momentos que serviram de base para a formação da sociedade e economia encontrada hoje no território.

A construção social da Amazônia se fez entre migrantes e não migrantes. Os índios aqui sempre residiram. Posteriormente, teve nos povos nordestinos, durante os ciclos da borracha, seus primeiros migrantes, eram forasteiros em busca de melhores condições de vida e que vinham fugindo de uma grande seca no sertão nordestino. Esse período marca-se muito mais pelo descompromisso social com a terra do que pela busca de uma verdadeira colonização do território (BENTES; AMIN, 2005).

Com o declínio do período extrativista da borracha, passam a ingressar à região amazônica exploradores de outras partes do país, especialmente sulistas que adentravam na Amazônia em busca de terras baratas para expandirem o agronegócio regional. Foi a partir dos anos 60 , com incentivos governamentais e projetos dirigidos de assentamentos humanos, que a migração sulista se expandiu regionalmente, especialmente com o avanço da fronteira agropecuária (BARROS et al., 2002).

Portanto, diante dessas considerações iniciais é que se buscou analisar, sociodemograficamente, o território rural da Amazônia brasileira, buscando entender as principais relações sociais e demográficas desencadeadas na região, fruto dos vários momentos históricos vividos. Mormente, focou-se no espaço rural devido esse ainda concentrar parcela significativa da sua população residente e guardar forte ligação econômica com a sociedade, explicando a importância que esse território ainda tem no contexto regional.

Para tanto, utiliza-se de variáveis sociodemográficas que expressam o contexto social atual da região. São dados oriundos do último Censo Demográfico do IBGE, referente ao ano de

\footnotetext{
${ }^{1}$ Neste estudo, a Amazônia brasileira se refere a macrorregião Norte do Brasil composta pelos estados do Acre, Amapá, Amazonas, Pará, Rondônia, Roraima e Tocantins.
} 
2010. A partir desses dados se traçam panoramas estaduais quanto a informações da sociedade rural nortista. Assim, cumpre-se mencionar que se trata de uma pesquisa qualitativa de cunho exploratório e de base de dados secundária.

Vale ressaltar que a Amazônia brasileira, ou região Norte do Brasil, é marcada pela sua vasta extensão territorial e predominância do bioma Amazônia. É composta por sete unidades federativas nacionais, sendo elas o Acre, Amapá, Amazonas, Pará, Rondônia, Roraima e Tocantins. Marca-se ainda por ser um território ainda "vazio" demográfica e economicamente, quando comparado com as demais regiões brasileiras (LOBÃO, 2018).

Além desta breve introdução, a pesquisa subdivide-se em mais quatro seções principais. A segunda seção trata de contextualizar o ambiente da Amazônia brasileira. A terceira fica com os aspectos metodológicos usados para concretização do trabalho, ficando o quarto tópico com a discussão dos principais resultados. As considerações finais sumarizam todo o exposto.

\section{Amazônia brasileira: contextualizando o ambiente regional}

A Amazônia brasileira integra o lado Oeste do Brasil e contempla, no seu território, sete unidades federativas, sendo os estados do Acre, Amapá, Amazonas, Pará, Rondônia, Roraima e Tocantins. É a região brasileira com maior área territorial do Brasil e tem como predomínio o bioma Amazônia, como mostra a Tabela 1, o que a insere em um contexto muito particular quando comparada com as demais macrorregiões brasileiras, assim como atraí os olhares da comunidade internacional, especialmente em decorrência da temática das questões ambientais.

\begin{tabular}{|c|c|c|c|}
\hline ESTADO & Área $\left(\mathrm{km}^{2}\right)$ & Bioma Amazônia $\left(\mathrm{km}^{2}\right)$ & (\%) Amazônia \\
\hline Acre & $153.149,90$ & $153.149,90$ & 100,00 \\
\hline Amapá & $143.453,70$ & $143.453,70$ & 100,00 \\
\hline Amazonas & $1.577 .820,20$ & $1.577 .820,20$ & 100,00 \\
\hline Pará & $1.253 .164,50$ & $1.253 .164,50$ & 100,00 \\
\hline Rondônia & $238.512,80$ & $235.650,64$ & 98,80 \\
\hline Roraima & 230.104 & 230.104 & 100,00 \\
\hline Tocantins & $278.420,70$ & $25.057,86$ & 08,99 \\
\hline TOTAL & $3.874 .625,80$ & $3.618 .400,80$ & 93,39 \\
\hline
\end{tabular}

Tabela 1 - Representação da área do Bioma Amazônia em cada estado da Amazônia brasileira. Fonte: Lemos; Silva (2011), com base em IBGE (2009). 
Em 2010, a região Norte brasileira, para fins de comparação, apresentou um Produto Interno Bruto - PIB com participação de 5,34\% do total nacional e uma taxa de crescimento do PIB regional de 7,50\% entre 2007 e 2010 (IBGE, 2010c). Nesse mesmo ano, abrigou cerca de $8,32 \%$ da população brasileira, porém ocupando um total de $45,26 \%$ do território nacional (IBGE, 2017). Apesar de toda essa representatividade, conforme a Companhia Nacional de Abastecimento - CONAB (2015), a região contribuiu apenas com 4,90\% da produção nacional inspecionada em 2014, em que, no primeiro trimestre, todos os estados da região apresentaram queda na produção.

De forma geral, verifica-se que a região Norte do Brasil possui baixa densidade populacional e a presença de grandes extensões de áreas microrregionais, conforme mostra a Figura 1. Essa região é marcada, ainda, assim como o Centro-Oeste e parte do Semiárido nordestino, pela baixa capacidade de absorção de mão de obra, isso associado ao dinamismo insuficiente de atividades produtivas que ali se realizam, bem como apresenta uma integração tardia ou deficiente com outros locais mais dinâmicos dentro do território nacional (BRASIL, 2005).

Essa particularidade de baixa densidade no território amazônico liga-se diretamente à presença frequente de demarcações de terras indígenas ou de unidades de conservação, acabando, de alguma forma, por limitar a ocupação humana, inclusive tendo rendido vários conflitos pela posse de terra na região. Não obstante, esse padrão de baixa distribuição populacional também se remete às origens do processo de colonização e ocupação do Brasil, uma vez que foi nas regiões litorâneas que a ocupação do território brasileiro ocorreu primeiro (BRASIL, 2005). 


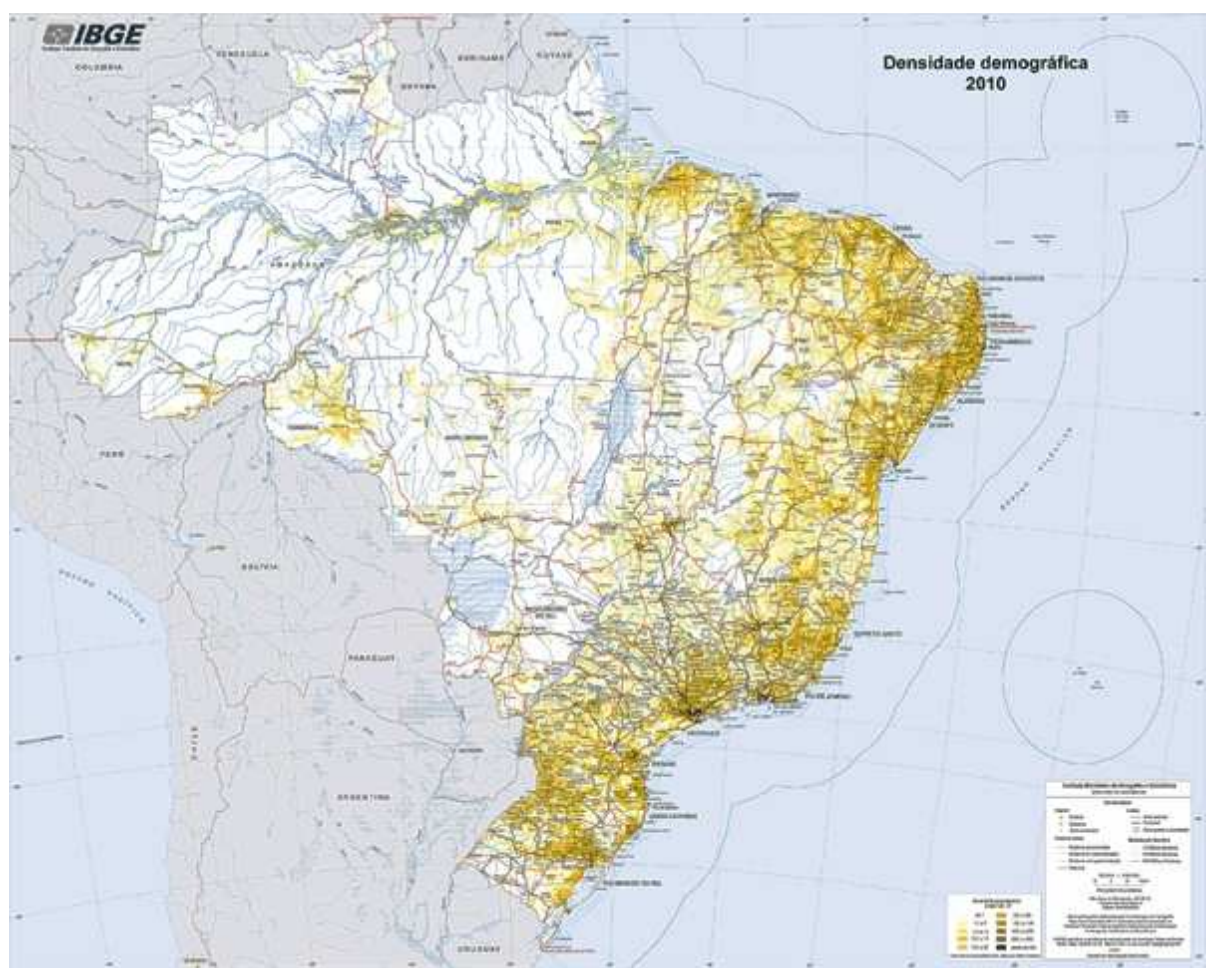

Figura 1 - Densidade demográfica brasileira com ênfase na Amazônia brasileira, 2010. Fonte: IBGE, 2010a.

Mormente, Moura e Moreira (2001, p. 219) enfatizam que tem havido um forte crescimento populacional na região nos últimos tempos. Afirmam que as tendências demográficas evolutivas no Norte brasileiro têm se destacado, historicamente, "[...] por apresentar taxas de crescimento quase sempre mais elevadas do que as do Brasil como um todo [...]".

Os autores reforçam, no entanto, que, a partir dos anos 1990, o ritmo desse crescimento caiu, atingindo uma média de 2,60\%, número demasiadamente inferior quando comparado com as taxas dos anos 70 e 80, de 4,70\% e 3,90\%, respectivamente. Entre os anos de 2000 e 2010, a taxa de crescimento da população do Norte brasileiro ficou em 2,86\% e 2,09\%, respectivamente, o que comprova essa redução contínua nos períodos mais recentes, porém bem acima da brasileira, que ficou, em 2010, na proporção de 1,17\%, conforme pode ser visualizado na figura 2 (SEPLAG, 2013). 


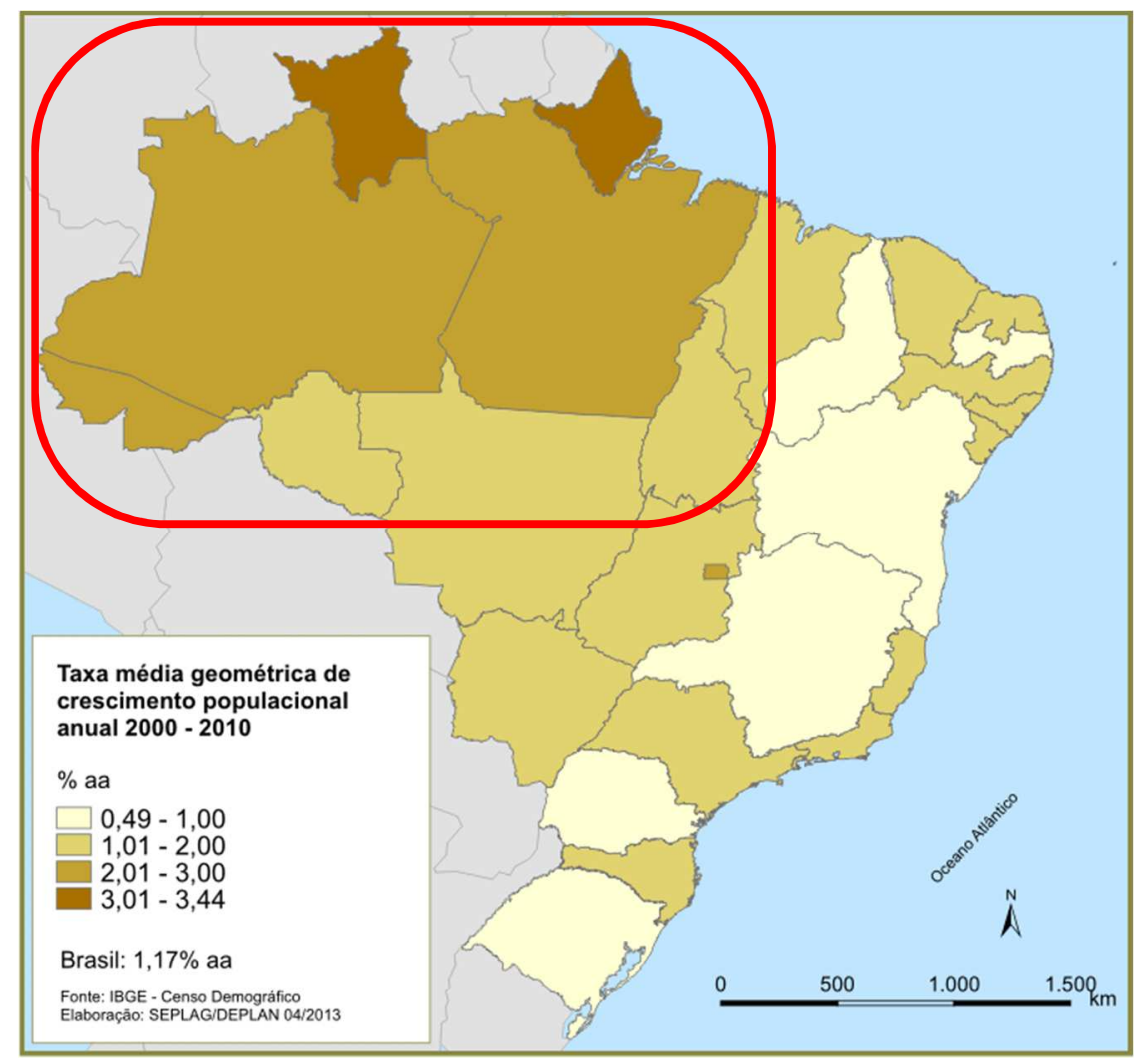

Figura 2 - Taxa geométrica de crescimento da população brasileira, com ênfase na Amazônia brasileira, 2010.

Fonte: SEPLAG/DEPLAN, 2013 com base em Censo Demográfico/IBGE, 2010.

O meio rural ainda é muito presente na vida das pessoas que na Amazônia vivem. Ao mesmo tempo esse meio é uma das principais formas de sobrevivência dos residentes. Destaca-se a produção do setor primário da economia, seja com o desenvolvimento da pecuária, da extração vegetal, de minérios ou da produção agrícola (DANTAS; FONTELES, 2004), ou mesmo com uma diversificada pauta de culturas e em expansão, pois que, conforme Barbosa (2015), na região Norte, entre 1995 e 2006, cresceu 276,00\% a área de lavouras temporárias e permanentes.

Por outro lado, a urbanização na região vem crescendo em ritmo acelerado, apesar de ainda possuir uma das menores taxas de urbanização em comparação com o restante do Brasil, como segue na Figura 3. Moura e Moreira (2001) explicam que é partir dos anos 1990 que se verifica uma forte redução no crescimento da população rural na região e aumento da população urbana.

Os autores chamam esse processo de "desruralização" e que chega com certo atraso em relação ao restante do país, pois, desde a década de 1960 e 70, o país já vinha passando por 
essa transição populacional. Assim, começa a aumentar, sobremaneira, o contingente de pessoas no meio urbano na região Norte brasileira.

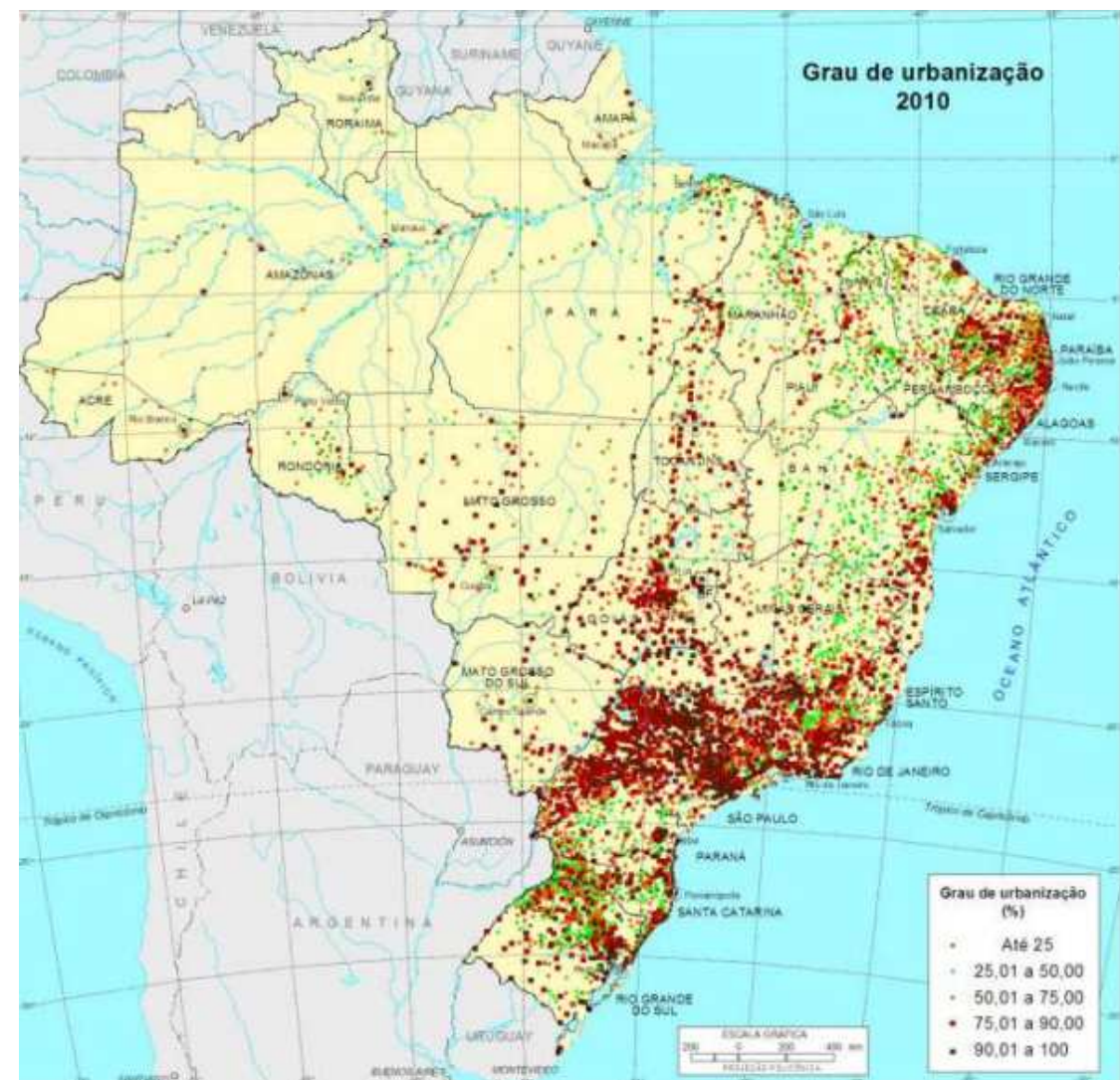

Figura 3 - Grau de urbanização brasileira, com ênfase na Amazônia brasileira, 2010. Fonte: IBGE, 2010a.

Moura e Moreira (2001) ainda explicam que, nos anos 1980, já se igualava na região o quantitativo de residentes no meio urbano em relação ao meio rural, passando para $58,00 \%$ no Censo de 1991, 62,00\% na Contagem Populacional de 1996 e quase 70,00\% no Censo Demográfico de 2000. Esses percentuais mostram que o crescimento líquido da população nortista de 72,00\%, entre 1980 e 1991, na ordem de 3,5 milhões de habitantes, foi gerado e/ou absorvido em cidades e vilas. Já entre 1991 e 2000, o percentual se elevou para mais de $115,00 \%$.

Em 2010, conforme o IBGE (2010a), a população urbana atingia o quantitativo de 11.664.509 habitantes, enquanto a população rural representava o total de 4.199.945 pessoas. Já eram mais de $73,00 \%$ da população residindo nos centros urbanos, porém com menor intensidade de crescimento populacional que no decênio anterior.

Bentes e Amin (2005, p. 8) complementam esses resultados indicando que, "[...] a partir de 1960, a urbanização da região Norte acontece com maior intensidade do que no Brasil, 
especialmente na década de 80 , quando a taxa de variação da urbanização regional $(131,77 \%)$ foi, aproximadamente, três vezes maior que a nacional $(53,01 \%)$ [...]". Essa urbanização acelerada na região tem sido atrelada, no entanto, a políticas públicas insuficientes na área propriamente rural. Ademais, com "[...] baixos investimentos relativos à ocupação do solo, abastecimento de água, saneamento básico, gerenciamento de resíduos sólidos e geração de emprego, colocaram milhões de pessoas em habitações insalubres, tanto em áreas metropolitanas, quanto nas cidades e vilas do interior" (BRASIL, 2004, p. 11).

Essa é a realidade, sem contar que a concentração populacional tem se dado principalmente nas capitais dos estados, como apontam Cardoso e Müller (2008). Decorre que, dada essa rápida urbanização, isso também tem custado caro ao meio ambiente, provocando graves problemas como "[...] lançamento de esgoto e efluentes agroindustriais e industriais não tratados, assim como o depósito de resíduos sólidos em terrenos baldios, rios e igarapés [...]" (GUTBERLET, 2000, p. 160).

São sobre essas acepções iniciais que se analisa, sociodemograficamente, o território rural da Amazônia brasileira. É um espaço regional que ainda guarda forte ligação com o meio rural, pois boa parte da sua população ainda reside nesse território e tem nas atividades produtivas primárias uma das suas principais fontes de sobrevivência, como é o caso da produção agropecuária, inclusive, com alta participação no Produto Interno Bruto da região e tem marcado as relações sociais e demográficas nas últimas décadas.

\section{Metodologia}

Para análise do território rural da Amazônia brasileira a partir das dimensões social e demográfica foi utilizado algumas variáveis sociodemográficos. Essas variáveis acabaram por evidenciar as principais relações sociais desencadeadas no território estudado, fruto das várias ações históricas incorridas à região até então.

É um estudo qualitativo com caráter exploratório. Qualitativo porque permite compreender determinado fenômeno dentro do seu contexto que é parte e se realiza, devendo as análises serem abordadas de forma integrada com o todo (GODOY, 1995). Exploratório 
devido buscar entender com maior familiaridade o ambiente regional focalizado, na expectativa de torná-lo mais claro e compreendido a partir de premissas pensadas com base em intuições, ideias e levantamentos de informações, especialmente na literatura disponível (SEVERINO, 2007; GIL, 2009).

Nesse sentido, utilizou-se um conjunto de dados que possibilitou analisar, comparativamente, o contexto sociodemográfico rural dos estados da região Norte do Brasil, organizados em tabelas e gráficos. Os constructos utilizados referiram-se a características populacionais como: sexo, idade, situação de domicílio, pirâmide etária, cor ou etnia, assim como de condições e qualidade de vida, como a presença ou ausência de infraestruturas sociais básicas, de desenvolvimento humano, de escolarização e trabalho infantil, conforme segue na tabela 2. Isto é, verificou-se entender como as condições sociodemográficas se comportou na Amazônia brasileira.

\begin{tabular}{|c|c|c|c|}
\hline Variável & Descrição & Fonte & Ano \\
\hline População & Total da população por estado & IBGE & 2010 \\
\hline Situação do domicílio & $\begin{array}{c}\text { Porcentagem da população que residiam na área urbana ou rural } \\
\text { dos estados }\end{array}$ & IBGE & 2010 \\
\hline Sexo & Porcentagem da população de homens e mulheres por estado & IBGE & 2010 \\
\hline Pirâmide etária rural & Distribuição da população etária por faixa de idade e sexo da \\
região & IBGE & 2010 \\
\hline Raça/Cor rural & Distribuição da população rural por cor ou raça da região & IBGE & 2010 \\
\hline $\begin{array}{c}\text { Infraestruturas sociais } \\
\text { rurais básicas }\end{array}$ & $\begin{array}{c}\text { Porcentagens dos estabelecimentos rurais com acesso à energia } \\
\text { elétrica, com saneamento básico inadequado, com } \\
\text { infraestrutura sanitária e com água encanada por estado }\end{array}$ & IBGE & 2010 \\
\hline $\begin{array}{c}\text { Escolarização rural } \\
\text { Porcentagens da população de 10 anos ou mais alfabetizada, } \\
\text { com frequência escolar e trabalho infantil }\end{array}$ & IBGE & 2010 \\
\hline
\end{tabular}

Tabela 2 - Variáveis sociodemográficas utilizadas nas análises.

Fonte elaborado pelos autores, 2018.

\subsection{Ambiente e universo da pesquisa}

A região Norte do Brasil, apresenta a totalidade de 450 municípios, distribuídos em sete estados brasileiros: Acre (22 municípios), Amazonas (62 municípios), Amapá (16 municípios), Pará (144 municípios), Rondônia (52 municípios), Roraima (15 municípios) e Tocantins (139 municípios). Possui uma larga faixa de fronteira, o que, inclusive, desperta interesses de segurança nacional, fazendo divisas com os países da Bolívia (Acre), Peru (Acre e Amazonas), 
Colômbia (Amazonas), Venezuela (Amazonas e Roraima), Guiana (Roraima e Pará), Suriname (Pará e Amapá) e Guiana Francesa (Amapá), como pode ser visto na figura 4.

É a macrorregião brasileira com maior extensão territorial, conta com $3.853 .843,71 \mathrm{~km}^{2} \mathrm{e}$ compõe a quase totalidade da Amazônia Legal brasileira, com exceção do estado de Mato Grosso e uma parte do Maranhão. Dentre seus sete estados, somente o Tocantins não possui a maior parte do seu território na Amazônia, apresentando apenas 8,99\% do território neste bioma e os outros $91,00 \%$ restantes no Cerrado brasileiro. Outro destaque refere-se ao fato de que a região detém o maior Estado brasileiro em extensão territorial, o Amazonas, e o maior município, Altamira, este, por sua vez, com limites geográficos maiores que o Estado de Sergipe (IBGE, 2016).

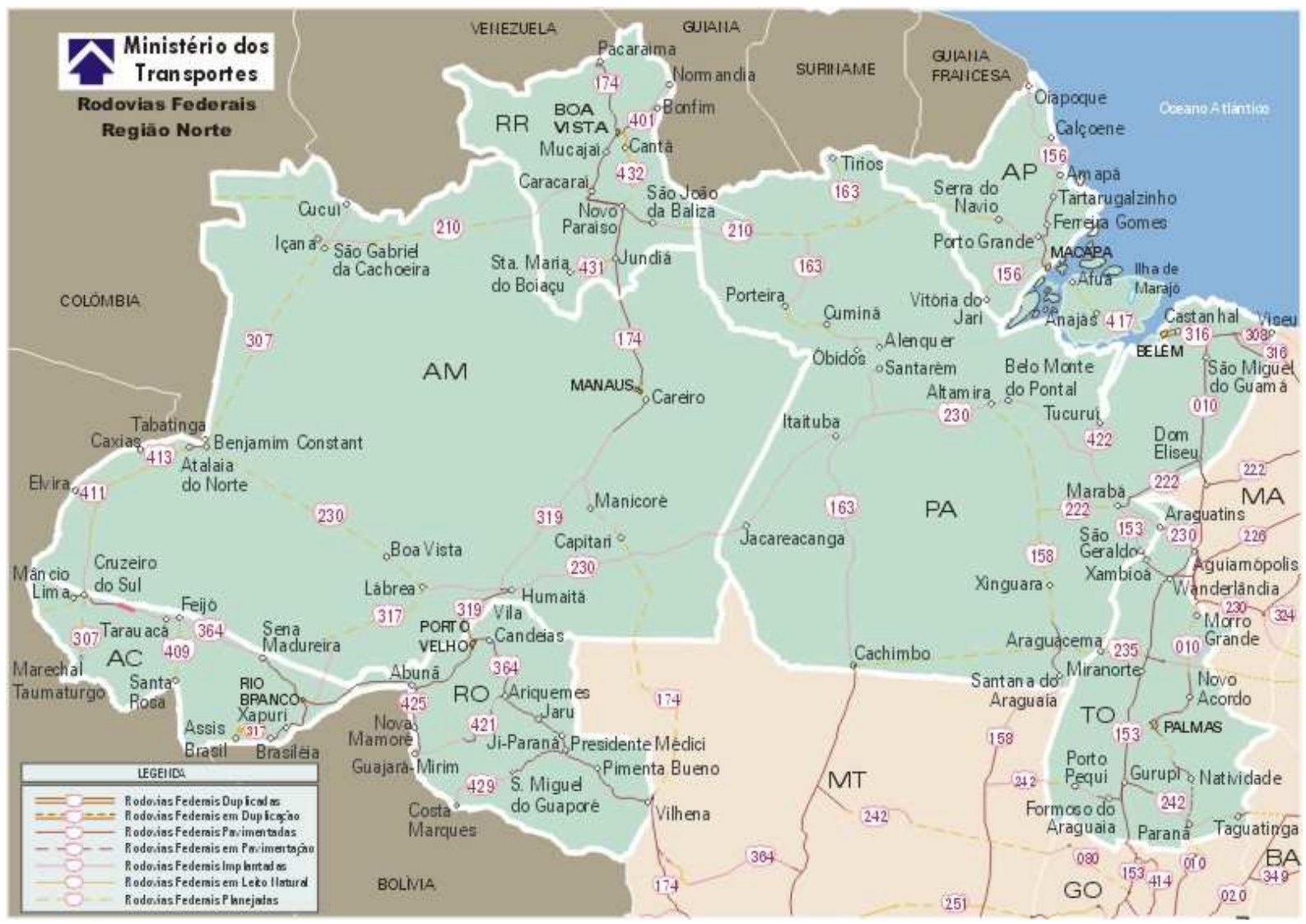

Figura 4 - Mapa da região Norte do Brasil.

Fonte: Ministério dos Transportes, 2017.

A participação da região Norte no Produto Interno Bruto brasileiro em 2012 foi de 5,3\% (IBGE, 2015), resultado bastante tímido, mas que não minimiza sua importância nacional, inclusive, global, especialmente, por ser considerada o "pulmão do mundo", com a maior extensão de faixa de floresta do planeta e maior biodiversidade em fauna e flora. Apesar do 
rendimento baixo no PIB nacional, em 2011, conforme dados da Pesquisa Nacional de Amostra por Domicílio, somente a região Norte apresentou aumento de concentração de renda, em comparação com as outras quatro regiões brasileiras.

\section{Analisando o território rural da Amazônia brasileira: evidências sociodemográficas}

\subsection{Características demográficas da população rural}

Demograficamente verifica-se que a Amazônia brasileira ainda é considerada uma região "vazia" de pessoas. Apresenta uma densidade demográfica muito baixa, especialmente se comparada com as demais macrorregiões brasileiras (BRASIL, 2005).

Esse fato decorre de questões históricas nacionais. A colonização e exploração no Brasil se deu primeiramente nas áreas litorâneas, ficando restrita ao Leste brasileiro. O Oeste do país ficou relegado e subutilizado por muito tempo.

Foi somente em meados do século XX que se começou a verdadeira inserção desta porção do território no contexto nacional. Esse processo se deu com uma intensa ocupação e exploração na década de 60 e 70, com o governo militar brasileiro, através dos planos governamentais desenvolvimentistas. Esses planos priorizaram a construção de rodovias e a promoção da colonização, bem como a incorporação da região na fronteira agrícola de produção como política de integração (BARROS et al., 2002).

Ademais, a grande maioria dos residentes da região sempre se encontraram aglutinados em pequenos espaços territoriais. São as capitais dos estados, especialmente, Manaus e Belém, e cidades de médio porte, como Santarém, Presidente Figueiredo e Paragominas, que acabaram por concentrar grande parte dos residentes regionais, provocando, inclusive, processos de suburbanização (GUTBERLET, 2000).

Surgiram verdadeiros polos demográficos. Houve a formação de uma larga faixa de terra desabitada, ocupada primordialmente por florestas nativas, com quase nenhuma ou 
pouquíssima ocupação e exploração humana, sejam por questões legais ou por dificuldades de acesso.

Oliveira (1996) afirma que são notados pelo menos quatro grandes polos ou eixos de ocupação na Amazônia. Esses polos ou eixos decorreram de ações específicas oriundas do Estado brasileiro ou do avanço da fronteira agrícola.

O primeiro deles refere-se à Zona Franca de Manaus, no qual se gerou um polo moderno de crescimento industrial. Visou-se aqui promover o desenvolvimento em áreas isoladas no interior da Amazônia ocidental.

No segundo, se observa por meio do polo Carajás, em que abrange o triângulo São Luiz, Marabá-Belém. Este polo tem como principal característica a boa disponibilidade de recursos naturais, especialmente de minérios.

Outro polo, de natureza agropecuária, decorreu do prolongamento do Centro-Oeste até a região Amazônica. Esteve diretamente vinculado aos esquemas de acumulação decorrentes dos estados como Minas Gerais e São Paulo, do Sudeste brasileiro.

Por fim, o quarto e último polo/eixo de ocupação, Oliveira (1996) considera como estritamente amazônico. Deu-se por meio de uma colonização orientada pelo Governo Federal, a partir do incentivo da vinda de pessoas oriundas de estados sulistas, com expertise na área agrícola e pequenos capitais. Foi nos estados de Rondônia e Acre que tais ações surtiram melhores efeitos, estas diretamente relacionadas a expansão da pecuária e agricultura.

No entanto, Moura e Moreira (2001, p. 216) complementam que, "na década de 80, quando se instala a crise financeira no Estado brasileiro e as políticas públicas perdem espaço, força e rigidez, a ocupação da região Norte passa acontecer, fundamentalmente, pela lógica do mercado". Os resultados dessa mudança acabam somente reforçando os polos/eixos de ocupação já consolidados, ficando a mercê o restante do território nortista.

Os autores realçaram ainda que o crescimento populacional vegetativo na região não seria capaz, por si só, de conseguir ampliar a base demográfica, ao ponto de aumentar, significativamente, a densidade demográfica regional. Assim, carece-se de movimentos migratórios inter-regionais para elevar a população local, como aconteceu no passado. 
Diante disto e embasados nos dados do Censo Demográfico de 2010 do IBGE, verificou-se que a região Norte contou com uma população total de 15.864.454 habitantes, conforme Tabela 3. Desse total da população regional $73,53 \%$ residiam no ambiente urbano e $26,47 \%$ no meio rural. A população da região representou apenas 8,32\% da população brasileira.

Verificou-se uma distribuição equitativa entre homens e mulheres. Essa tendência foi seguida por todos os estados, predominando sutilmente o sexo masculino sobre o feminino, quando considerado o meio urbano e o rural em conjunto. No entanto, nacionalmente a tendência se inverte, pois, as mulheres foram maioria.

\begin{tabular}{lccccc}
\hline \multirow{2}{*}{ Estado } & População & \multicolumn{2}{c}{ Situação do domicílio } & \multicolumn{2}{c}{ Sexo } \\
\cline { 3 - 6 } & Total & Urbana (\%) & Rural (\%) & Homem (\%) & Mulher (\%) \\
\hline Acre & 733.559 & $\mathbf{7 2 , 5 6}$ & 27,44 & 50,21 & 49,79 \\
Amapá & 669.526 & 89,77 & 10,23 & 50,06 & 49,94 \\
Amazonas & 3.483 .985 & 79,09 & 20,91 & 50,32 & 49,68 \\
Pará & 7.581 .051 & 68,48 & 31,52 & 50,41 & 49,59 \\
Rondônia & 1.562 .409 & 73,55 & 26,45 & 50,89 & 49,11 \\
Roraima & 450.479 & 76,55 & 23,45 & 50,80 & 49,20 \\
Tocantins & 1.383 .445 & $\mathbf{7 8 , 8 0}$ & 21,20 & 50,77 & 49,23 \\
Região norte & $\mathbf{1 5 . 8 6 4 . 4 5 4}$ & $\mathbf{7 3 , 5 3}$ & $\mathbf{2 6 , 4 7}$ & $\mathbf{5 0 , 4 6}$ & $\mathbf{4 9 , 5 4}$ \\
Brasil & $\mathbf{1 9 0 . 7 5 5 . 7 9 9}$ & $\mathbf{8 4 , 3 6}$ & $\mathbf{1 5 , 6 3}$ & $\mathbf{4 8 , 9 7}$ & $\mathbf{5 1 , 0 3}$ \\
\hline
\end{tabular}

Tabela 3 - População residente nos estados da Amazônia brasileira, por situação do domicílio e sexo, 2010 (\% em relação ao estado, região e Brasil).

Fonte: IBGE/Censo Demográfico, 2010d.

Pará foi o estado com maior contingente de pessoas. Foi também o estado da região com maior quantitativo de indivíduos residindo no meio rural, $31,52 \%$ do total.

Mediante IBGE (2013, p. 19) a distribuição da população no território paraense tem na região metropolitana de Belém a maior expressividade. Conforme a Instituição "[...] A Mesorregião Metropolitana de Belém contribuiu com $27,73 \%$ da população total estadual e 70,56\% de seu contingente populacional estava com menos de 40 anos [...]". Respectivamente, após a Mesorregião Metropolitana de Belém, se tem as Mesorregiões do Nordeste e Sudeste Paraense como as mais populosas.

Outro estado de destaque foi Rondônia, teve o terceiro maior contingente populacional da região, atrás somente do Pará e Amazonas, este último explicado pela presença da Zona Franca de Manaus. É na década de 70 que em Rondônia são criados projetos de assentamentos humanos dirigidos, experimentando um crescimento populacional 
vertiginoso, com a imigração de pessoas de outras regiões do país, especialmente do estado do Paraná (SOUZA; PESSÔA, 2009).

Foi a partir do fechamento da fronteira de produção no Paraná, da modernização do campo e da tensão agrária no Nordeste que se intensificam a ocupação na Amazônia brasileira, com destaque para Rondônia. Os migrantes paranaenses em Rondônia somavam, na década de 1970, cerca de 40,00\% nos assentamentos dirigidos pelo INCRA (SOUZA; PESSÔA, 2009).

O estado do Amapá destacou-se aqui por concentrar $89,77 \%$ dos seus habitantes com domićlios no meio urbano e apenas $10,23 \%$ no meio rural. Sousa (2006) afirma que isso é fruto de três grandes fluxos migratórios no estado, a partir da segunda metade do século XX. O primeiro foi resultado do desmembramento do Pará e a sua elevação a categoria de Território Federal em 1947, em que o desenvolvimento das infraestruturas sociais foram os responsáveis por essa migração. Atrelados a isto, houve em 1953, no município de Serra do Navio, a instalação da empresa ICOMI (Indústria e Comércio de Minérios do Amapá), que se destacou por ser um grande projeto multinacional de extração do Manganês.

O segundo fluxo de pessoas se deu no final da década de 1960 com a exploração do caulim e da formação do complexo agrosilvipastoril de D. Ludwig (Projeto Jari), no vale do Jari. Esse fluxo decorreu da vinda de brasileiros, principalmente paraenses, na busca de empregos e salários em instituições públicas, bem como na empresa ICOMI e Projeto Jari (SOUZA, 2006).

Por fim, o terceiro fluxo migratório no Amapá datou do final da década de 1980 e início de 90. Para Sousa (2006, p. 20) é a criação da Área de Livre Comércio em Macapá e Santana (ALCMS) o principal responsável. O autor explica que neste fluxo "[...] a atração se apresenta de forma difusa. Indo da possibilidade de obter empregos nas 'importadoras', pela abertura de um 'negócio' de compra e venda de produtos importados no mercado formal, ou de outros serviços, principalmente de venda de bebidas e alimentos preparados".

O território roraimense apresentou o menor quantitativo de residentes frente aos demais estados da região. É um estado ainda em plena expansão ocupacional e econômica, especialmente através de suas fronteiras com Venezuela e Guiana. Silva e Silva (2004) revelam que o dinamismo demográfico em Roraima se inicia somente na década de 1970 e, especialmente na década de 80. Esse dinamismo tem se dado a partir de migrantes, com 
destaque a pessoas naturais do Maranhão, que, conforme os autores, no Censo de 2000 representavam cerca de $38 \%$ do total da população do estado.

Conforme o IBGE (2006) a expansão ocupacional e econômica de Roraima tem se dado, principalmente em áreas urbanas. Como visto na Tabela 2 , foram mais de $76,00 \%$ dos residentes no meio urbano em 2010. A Instituição esclarece ainda que esse crescimento urbano tem ocorrido devido a frágil política agrícola, empurrando a população aos centros urbanos, com destaque aos vários órgãos do serviço público criados a partir da criação do estado em 1988 através da Constituição Federal.

Historicamente, no meio rural brasileiro as condições de vida sempre foram mais difíceis do que no meio urbano. As dificuldades de acesso a uma melhor educação, saúde, infraestrutura ou um trabalho com características mais desgastantes explicam isto.

Não menos diferente, as transformações populacionais também tendem a ocorrer de maneira mais demorada no ambiente rural. Leva-se um maior lapso temporal para que transições demográficas aconteçam, como é o caso da diminuição da taxa de natalidade, de mortalidade ou expectativa de vida, especialmente na Amazônia brasileira que possui uma colonização tardia.

Por exemplo, conforme Moura e Moreira (2001), existe uma grande defasagem da população rural amazônica em relação à população urbana quanto a evolução da fecundidade. No período de 1990/95, verificaram-se níveis elevados de fecundidade no meio rural (5,6 filhos por mulher) em relação ao meio urbano amazônico (3,6 filhos por mulher). Em relação a esperança de vida ao nascer, os números até que se equipararam, com valor aproximado de 66 anos, no mesmo período.

Nesse sentido, na região Norte, com a representação da pirâmide etária da população rural disposta no Gráfico 1, verificou-se uma base piramidal alargada, especialmente entre os anos de 0 a 14 anos, demonstrando que ainda persistem altas taxas de natalidade. Não obstante, notou-se ainda uma abrupta redução das pessoas a partir dos 15 anos de idade. 


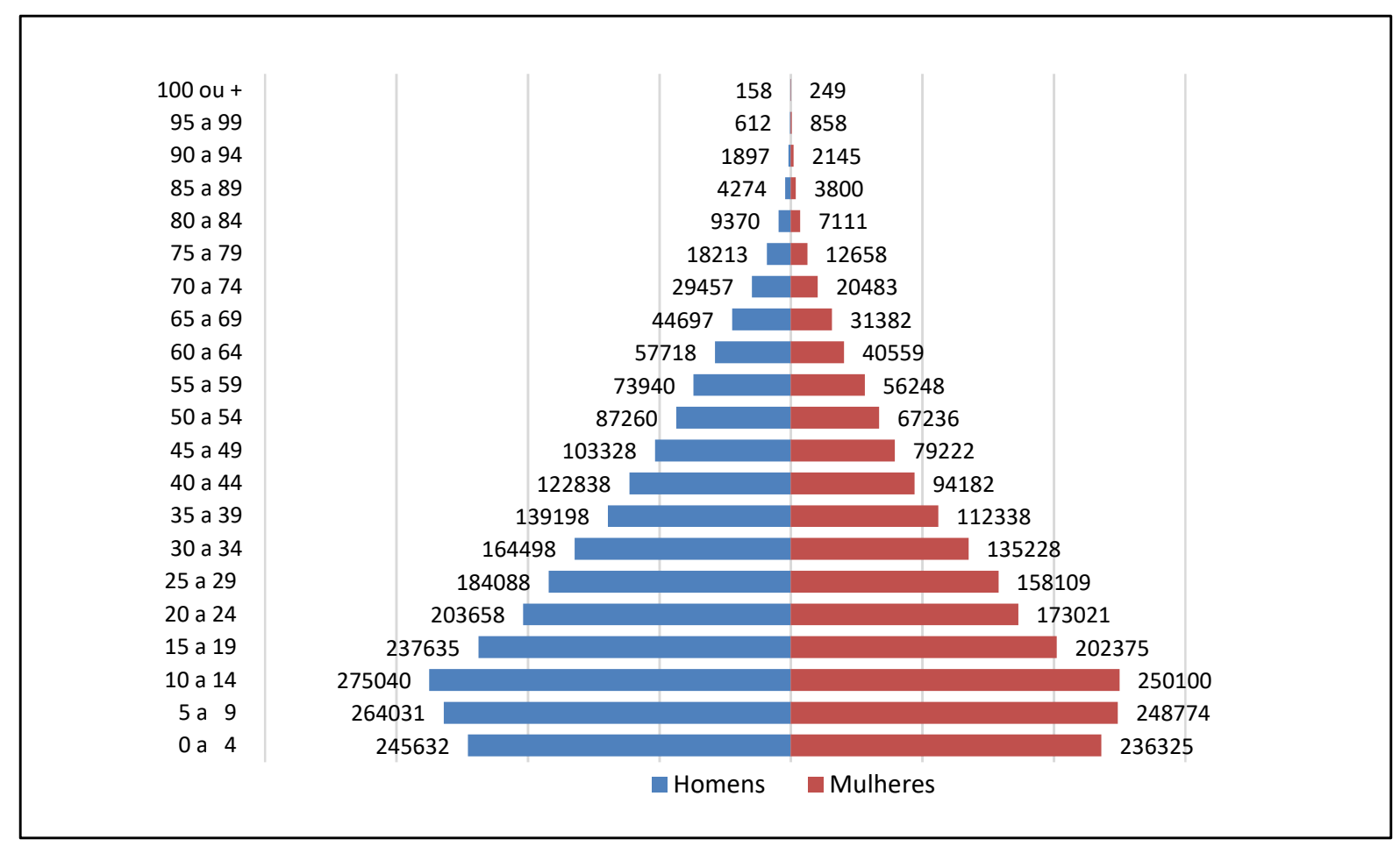

Gráfico 1 - Pirâmide etária rural por sexo da Amazônia brasileira, 2010.

Fonte: IBGE/Censo Demográfico, 2010d.

Supõe-se que essa diminuição de residentes com 15 anos ou mais decorre do êxodo para o meio urbano. É a partir dessa idade que a pessoa se torna parte da população economicamente ativa e busca, na cidade, melhores condições de vida através de um trabalho que Ihe proporcione isso. CEPAL (2014, p. 62) explicam que no Brasil, de forma geral, o crescimento da população no meio urbano tem sido motivado, "[...] entre outros aspectos, pela atração da oferta de serviços públicos, especialmente no campo da saúde e educação, e a geração de emprego e renda na área de serviços e indústria [...]".

Portanto, os atrativos urbanos pesam sobremaneira na decisão de migrar, bem como a qualidade de vida que lhe é vislumbrada. Matos (2012) explica ainda que a migração do tipo campo-cidade está para além dos atrativos urbanos, pois se deve considerar também o processo de expulsão do campo das pessoas por vários motivos, como: a modernização agrícola e a concentração latifundiária.

Os homens foram maioria no meio rural nortista. Esse resultado mostrou um processo de masculinização no campo da Amazônia brasileira. Camarano e Abramovay (1999) demonstraram essa tendência para o Brasil ao traçar um panorama nacional na década de 50. Explicam que esse processo decorreu amplamente das migrações da população jovem e 
feminina do campo para a cidade, não sendo diferente na região, conforme Gráfico 1, lado direito.

A população nortista teve no seu processo de colonização dois momentos principais. $O$ primeiro se deu com a vinda de nordestinos, incentivados pelo Estado brasileiro para explorar e extrair o látex da seringueira na região para a produção da borracha, no final do século XIX. O segundo momento foi mais recente, na década de 60 . Também incentivado pelo Estado, com o avanço da fronteira agrícola de produção, se estimulou a exploração agrícola da região. Houve a predominância de migrantes sulistas, especialmente paranaenses (BENTES; AMIN, 2005).

Portanto, houve uma mistura de etnias no contexto regional. Inicialmente, predominavam a população indígena, primeiros habitantes, depois surgiram os nordestinos e, por último, migrantes do Centro-Sul brasileiro.

Nesse contexto, verificou-se que houve uma forte miscigenação na região, característica que não foge à regra em âmbito nacional. Isto proporcionou a consolidação de uma população parda na região Norte do Brasil, como pode ser visto no Gráfico 2.

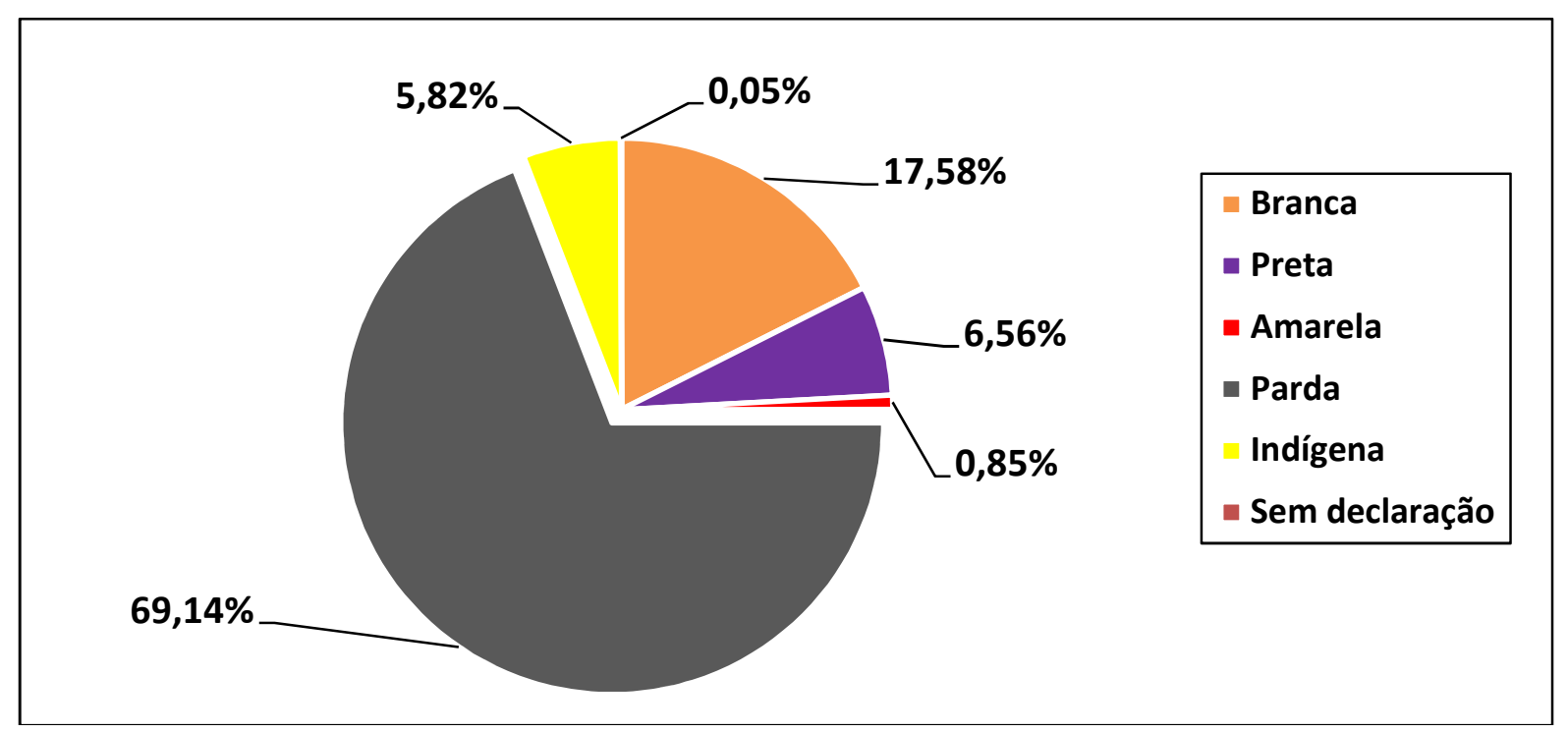

Gráfico 2 - Distribuição da população rural por cor ou raça na Amazônia brasileira, 2010. Fonte: IBGE/Censo Demográfico, 2010d.

O resultado da distribuição cor/etnia da população rural nortista demonstra que, culturalmente, existe uma riqueza na região, pois, mistura povos, costumes e tradições diversas, que no seu agregado integralizam a identidade regional do Norte brasileiro. 
O Pará, estado mais populoso da região, teve no seu processo de miscigenação a contribuição de pessoas brancas oriundas de vários países. Inicialmente foram levas migratórias de portugueses, espanhóis e holandeses e, posteriormente, japoneses, libaneses e italianos, sem contar vários judeus de nacionalidades diversas. Grupos de Ameríndios e negros trazidos da África completaram a base do processo de miscigenação do estado (IBGE, 2013).

Ademais, a região Norte brasileira, em especial estados como Acre, Amazonas, Amapá e Roraima, é vista como um território indígena e os dados mostraram que apenas $5,82 \%$ da população enquadraram-se nesta etnia, lembrando que aqui se trata dos residentes rurais. De todo modo, conforme Brasil (2004, p. 14), os povos indígenas vêm apresentando crescimento populacional na região amazônica na última década, em que apresentaram taxas superiores tanto a média regional como a nacional, "[...] alcançando-se uma população de 400 mil índios, e cerca de 200 mil 'aldeiados', ou seja, habitando ou referenciando-se a 'terras indígenas' reconhecidas ou a serem reconhecidas a partir dos preceitos da legislação brasileira".

\subsection{Condições das infraestruturas domiciliares rurais na amazônia brasileira}

Visando captar as condições de vida das pessoas no meio rural nortista utilizou-se informações sobre a infraestrutura domiciliar básica, como é o caso de acesso à energia elétrica, água encanada, saneamento básico, dentre outros. Além disto, as análises das condições de infraestruturas básicas acabam retratado a vulnerabilidade das famílias rurais e sua condição de pobreza. Sobre isso, Kreter, Del-Vacchio e Staduto (2015), analisando condições habitacionais como indicador de pobreza em áreas rurais do Nordeste, verificaram o quanto as condições habitacionais contribuem para o agravamento da condição de pobreza da população rural daquela região.

Os autores destacaram a necessidade de investimentos em saneamento e água potável, bem como o fortalecimento de ações básicas da saúde como condição de melhoria e superação da pobreza, que é endêmica no Nordeste brasileiro. Assim, a Tabela 4 trouxe o quantitativo de estabelecimentos rurais do Norte do Brasil com acesso a infraestruturas básicas. 


\begin{tabular}{lccccc}
\hline & Total Estab. & \% Ener. Eletr. & \% San. Bás. Inadeq. & \% Infra. San. & \% Água Enc. \\
\hline ACRE & 46.102 & 74,14 & 83,16 & 28,88 & 7,41 \\
AMAPÁ & 14.976 & 85,10 & 65,05 & 52,65 & 20,39 \\
AMAZONAS & 140.899 & 65,34 & 84,77 & 27,18 & 10,01 \\
PARÁ & 538.560 & 75,79 & 65,15 & 44,99 & 23,00 \\
RONDÔNIA & 117.146 & 89,81 & 83,52 & 76,16 & 3,18 \\
RORAIMA & 23.603 & 62,97 & 67,50 & 49,79 & 24,20 \\
TOCANTINS & 81.870 & 78,00 & 74,80 & 54,81 & 19,99 \\
REGIÃO & $\mathbf{9 6 3 . 1 5 6}$ & $\mathbf{7 5 , 9 0}$ & $\mathbf{7 4 , 8 5}$ & $\mathbf{4 6 , 4 7}$ & $\mathbf{1 7 , 6 7}$ \\
\hline
\end{tabular}

Tabela 4 - Estabelecimentos rurais da Amazônia brasileira por condições de infraestrutura básica, em porcentagem por estado, 2006.

Fonte: IBGE/Censo Demográfico, 2010d.

Dentre os resultados das quatro variáveis expostas, verifica-se que o acesso à energia elétrica na região é a que apresenta maior cobertura nos domicílios rurais. Por outro lado, a situação de residências sem acesso à água encanada é preocupante, assim como foi com o acesso a infraestrutura sanitária e sem saneamento básico adequado.

Em âmbito estadual, esses resultados foram diversos. O que se viu foi um padrão extremamente heterogêneo e desigual entre as condições básicas de infraestrutura nos estabelecimentos rurais dos estados.

Rondônia apresentou a maior taxa de acesso à energia elétrica e infraestrutura sanitária. No entanto, teve as piores porcentagens em relação ao total de estabelecimentos rurais com saneamento básico inadequado e com água encanada. Sem contar que foi o estado com o terceiro maior número de moradias rurais, com 117.146 residências, perdendo em importância apenas para o estado do Pará e Amazonas, o que intensifica os resultados observados.

Cabe, ainda, destaque negativo para Roraima que ficou com a menor taxa de acesso à energia elétrica, seguido por Amazonas, Acre e Pará. Em relação ao estado com piores níveis de saneamento básico inadequado, foi o Amazonas quem liderou, acompanhado de Rondônia e Acre.

No caso do Acre CEPAL (2014, p. 10) mostram que existe uma baixa cobertura da rede de esgotamento sanitário. Foram quase dois terços das residências acreanas sem acesso a esse serviço público em 2010, em que “[...] O sistema de esgotamento sanitário nos municípios 
do interior simplesmente não existe. Na capital (Rio Branco), apenas aproximadamente $22 \%$ do município estaria coberto por esse serviço".

O Amapá foi o terceiro estado com melhor nível de abastecimento de água rural. Esse resultado teve melhoras significativas em uma década, pois Domingues (2004), analisando dados do Censo Demográfico de 2000, alertava para a baixa prestação de serviços básicos à população, afirmando ser preocupante a situação até então encontrada. Os serviços de saneamento básico e drenagem pluvial eram precários e não atendiam as demandas dos centros urbanos.

A autora colocava que do total de 98.576 residências contabilizadas à época no estado, apenas 50,75\% tinham abastecimento de água oriundo da rede geral. Nos dois maiores municípios, Macapá e Santana, esse atendimento era de 53,25\% e 54,96\%, respectivamente, sendo constantemente encontrado nos domicílios o uso de água não tratada e/ou com canalização clandestina.

No Pará, conforme IBGE (2013), também se verificou um alto déficit de acesso a água tratada pela população, em que apenas 1,43\% dos 143 municípios do estado recebiam água tratada por meio do sistema de abastecimento. A maioria das famílias dos municípios paraenses acabam se abastecendo com água através de poços profundos. De modo geral, estipula-se que cerca de 50,00\% dos paraenses não têm acesso a água encanada e tratada devidamente para o consumo, apesar de conter a maior bacia hidrográfica do planeta.

\subsection{Características educacionais na amazônia rural brasileira}

Aspectos educacionais também foram analisados para a região, pois a educação é um indicador social muito importante, especialmente no âmbito rural. Trabalhadores e empregadores mais qualificados apresentam melhores rendimentos nas suas funções e, portanto, acabam gerando maiores excedentes de produção, favorecendo para um crescimento econômico elevado e, consequentemente, aumento de renda real.

Sobre isto, Freitas, Bacha e Fossati (2007, p. 122) ressaltam que "[...] a pobreza e a riqueza dos estados estão, em grande medida, relacionadas às habilidades e conhecimento médio dos seus trabalhadores". Não obstante, Costa e Cunha (2010), em pesquisa sobre os 
determinantes do desemprego no Brasil, concluíram que quanto menores forem as instruções dos trabalhadores, sejam homens ou mulheres, maiores são a probabilidade de estarem desempregados. Nesse contexto, enfatizam a necessidade de maiores qualificações dos trabalhadores como meio para diminuir a incidência de desemprego no Brasil.

No meio rural, um trabalhador com maior estoque de conhecimento consegue atingir maiores níveis de abstração. Torna-se mais dinâmico no aprendizado e no desenvolvimento de tarefas. Por parte dos agropecuaristas, especialmente aqueles pequenos e médios produtores, quanto maiores seus níveis educacionais mais fáceis acabam tomando decisões de onde, quando e como investir. Findam por melhor realocar seus recursos na presença de uma mudança de conjuntura, por exemplo. (FREITAS; BACHA; FOSSATI, 2007).

Além disto, mais anos de estudos tendem a representar melhores remunerações. Sobre isto, Cunha e Games (2013), constataram que a educação representou grande determinação na diferença salarial dos trabalhadores, especialmente dos paranaenses, objeto de estudo dos autores. Chegaram ao resultado de que a cada ano adicional de estudo, em 2009, havia cerca de $10,80 \%$ de retorno salarial, realçando a importância da mão de obra qualificada, tanto em termos de retorno para o próprio trabalhador como para a economia local.

Nesse sentido, a Tabela 5 traz informações relacionadas à educação do meio rural do Norte brasileiro. São apresentadas as porcentagens de alfabetização rural, frequência escolar e trabalho infantil por estado. Ressalta-se que o trabalho infantil impacta diretamente na educação das crianças, pois elas deixam de ir para a escola e acabam indo trabalhar no campo. Além disto, Dias e Araújo (2013) reforçam que o trabalho de crianças e adolescentes acaba por favorecer a condição de pobreza das famílias no presente e sendo o elo para essa pobreza no futuro.

Assim sendo, identificou-se que, regionalmente, $79,99 \%$ das pessoas eram alfabetizadas. Aqui se alerta para o fato desse dado poder guardar falsas impressões, haja vista essa alfabetização poder ser mínima, em que as pessoas estejam sabendo somente escrever e ler seu próprio nome ou, minimamente, conseguindo realizar as quatros operações matemáticas básicas. Portanto, se faz necessário maiores evidências empíricas. 


\begin{tabular}{cccc}
\hline & \% Pop. Alfab. 10> & \% Frequência escolar & \% Trab. Inf. \\
\hline Acre & 71,52 & 43,84 & 73,03 \\
Amapá & 81,91 & 19,05 & 38,14 \\
Amazonas & 76,74 & 40,81 & 57,69 \\
Pará & 80,45 & 47,59 & 67,70 \\
Rondônia & 87,42 & 34,30 & 64,06 \\
Roraima & 77,17 & 50,68 & 64,17 \\
Tocantins & 78,77 & 28,59 & 37,32 \\
Região & $\mathbf{7 9 , 9 9}$ & $\mathbf{4 2 , 3 6}$ & $\mathbf{6 2 , 3 8}$ \\
\hline
\end{tabular}

Tabela 5 - Alfabetização rural, frequência escolar rural e trabalho infantil rural na região Norte brasileira, por estado e região (em \%).

Fonte: IBGE/Censo Demográfico, 2010d.

Corroborando com essas preocupações, Freitas, Bacha e Fossati (2007, p. 121), observando as condições de desenvolvimento do setor agropecuário brasileiro, identificaram que, no período de 1980 a 2000, em termos relativos, “[...] os estados da Região Norte não conseguiram acompanhar, em termos do crescimento da escolaridade, o desempenho médio dos demais estados, no que se refere ao setor agropecuário [...]".

Rondônia foi o estado com melhor nível de alfabetização. Este resultado foi seguido pelo Amapá e Pará, ou seja, os três estados com taxa de alfabetização acima da média regional.

O estado do Amapá tem melhorado significativamente a escolarização da população rural. Foi o segundo melhor estado da região com o melhor nível de alfabetização rural. No entanto, nem sempre foi assim, como mostra Armelin (2001) ao estudar 54 comunidades rurais no estado, distribuídos nos municípios de Ferreira Gomes, Laranjal do Jarí, Macapá/Bailique, Mazagão, Pedra Branca, Porto Grande, Serra do Navio e Vitória do Jarí.

Conforme o autor, nestas 54 comunidades, à época, se verificavam a oferta de educação apenas até o ensino fundamental e precariamente. Eram $58,00 \%$ das comunidades com ensino até a 4 a série, $14,00 \%$ até a 8 a série, $2,00 \%$ até a $2 \underline{a}$ série, $4,00 \%$ apenas alfabetização, 4,00\% até a 7ạ série e 4,00\% com educação até a 5 a série. Ainda, do total das comunidades, $14,00 \%$ delas não tinham escolas. Caso os adolescentes quisessem ter acesso a nível educacional mais elevado eram obrigados a se encaminharem a centros maiores como Mazagão e Santana.

No estado do Acre CEPAL (2014) explicam que, apesar dos grandes esforços na redução do analfabetismo, o estado ainda se encontra com a pior classificação entre os demais da 
região Norte, com uma taxa de 16,50\% de pessoas de 15 anos ou mais analfabetas em 2010. Vale frisar que do total de analfabetos do Acre, $63,00 \%$ diziam respeito a pessoas com faixa etária acima de 40 anos, sendo a maioria referente ao interior do estado.

Sobre o trabalho infantil, Dias e Araújo (2013) mostram que, entre 2000 e 2010, houve uma redução na ordem de 6,80\% na região Norte do Brasil. No entanto, o autor alerta que essa diminuição não representou, em termos absolutos, diminuição da quantidade de crianças e adolescentes trabalhando ou buscando trabalho, sendo a única região do país nesta situação.

Considerando que houve um aumento demográfico na região, mesmo com a queda na taxa de trabalho infantil, se verificou um crescimento de 366.323 para 378.994 , de 2000 para 2010, do número de crianças e adolescentes trabalhando. Portanto, em termos absolutos, houve um acréscimo de 12,7 mil, contrariando a falsa ideia de queda trazida pela diminuição da taxa de trabalho infantil (DIAS; ARAÚJO, 2013).

Portanto, entende-se que a região Norte do país ainda concentra indicadores sociais precários se comparados com o restante do Brasil. Intrarregionalmente, verifica-se uma situação difusa entre os estados da região. No entanto, estados como Rondônia, Pará e Tocantins apresentam condições sociais com melhores resultados, refletidos nos seus níveis de desenvolvimento humano e por serem hoje os principais estados inseridos na fronteira agrícola de produção, trazendo maiores fluxos de pessoas, investimentos em capital produtivo e, consequentemente, sendo reivindicado mais e melhores infraestruturas sociais, como educação, saúde, enfim, qualidade de vida.

\section{Considerações finais}

Traçou-se como objetivo analisar, sociodemograficamente, o território rural da Amazônia brasileira. Para tanto, foi utilizado, metodologicamente, uma abordagem qualitativa de cunho exploratório a partir de dados do Censo Demográfico brasileiro de 2010, disponibilizado pelo IBGE. Ainda foram usadas literaturas especializadas para melhor explicar os resultados encontrados. 
A Amazônia brasileira, ainda hoje, é considerada uma região com baixa densidade demográfica, representando um "vazio" populacional, em comparação com as demais regiões do país. A maioria dos seus residentes encontram-se aglutinados em pequenos espaços regionais, especialmente nas capitais Manaus e Belém, assim como em cidades de médio porte como Santarém (PA), Presidente Figueiredo (AM) e Paragominas (PA). Verificou-se, de um lado, verdadeiros polos de concentração demográficos e, de outro, uma larga faixa de território pouco ou totalmente desabitada.

A população da região Norte, em 2010, somou um total de 15.864 .454 habitantes, representando $8,32 \%$ da população nacional, que, conforme o IBGE, 73,53\% viviam na área urbana e apenas $26,47 \%$ residiam no meio rural. Do total de habitantes, $50,46 \%$ eram de homens e 49,64\% de mulheres.

Nas análises da pirâmide etária da população rural em 2010, observou-se uma base piramidal alargada, especialmente entre os 0 a 14 anos. Na classe das pessoas de 15 anos ou mais de idade ocorreu uma rápida redução, indicando que os jovens quando começaram a se inserir no mercado de trabalho migraram para os centros urbanos em busca de melhores condições de vida, provocando o chamado êxodo rural. A população rural teve, ainda, como característica ser formada pela maioria de homens, com percentual de 53,99\% do total, demonstrando um processo de masculinização do campo.

Predominaram as pessoas de cor/raça parda no meio rural da região, com 69,14\% do total; seguidas por brancos, com 17,58\%; negros, com 6,56\%; e indígenas, com 5,82\%. Isto traz a forte evidência do processo de miscigenação do povo nortista, frutos de colonização, em um primeiro momento, de nordestinos e, posteriormente, por migrantes do Centro-Sul do país. Nas condições básicas de moradia, verificou-se que, do total de 963.156 moradias rurais, 75,90\% possuíam energia elétrica. Esse resultado foi fruto do programa governamental "Luz para Todos", implantado a partir dos anos 2000 e que permitiu uma disseminação universal do acesso à energia elétrica em todas as regiões do país. Por outro lado, mais de $74,00 \%$ demonstraram possuir saneamento básico inadequado, bem como mais de $46,00 \%$ das residências não tinham infraestrutura sanitária, isto é, banheiro estruturado, e apenas 17,67\% detinham água encanada, resultados preocupantes.

Em termos educacionais, ficou claro que $79,90 \%$ da população rural de 10 anos ou mais era alfabetizada em 2010. Porém valeu a ressalva de que esses dados poderiam estar 
escondendo o chamado alfabetismo funcional, ou seja, pessoas que apenas sabiam ler e escrever seu nome e pouco interpretavam um texto ou eram capazes de processar as operações básicas da matemática, carecendo de maiores evidências empíricas, o que se indica para pesquisas futuras.

A não frequência escolar apresentou um alto índice na região. Foram mais de $42,0 \%$ da população rural entre 10 a 17 anos que não iam à escola, isto em relação ao público urbano. Apesar da taxa ser menor no meio rural em relação ao urbano, ainda é preocupante pelo seu elevado índice.

O mais alarmante foi a situação do trabalho infantil, em que $62,38 \%$ das crianças entre 10 a 13 anos que trabalhavam encontraram-se na zona rural. Os estados do Acre, Pará, Rondônia e Roraima foram os que mais pecaram neste cenário de exploração infantil no meio rural. Portanto, nota-se que o território da Amazônia brasileira, também conhecida como região Norte do Brasil merece atenção redobrada na adoção de políticas públicas promotoras do desenvolvimento humano e aumento na qualidade de vida dos residentes rurais. As condições de vida ainda se encontram precárias nesse espaço territorial, assim como as transformações demográficas na região tem se mostrado com atraso, se comparada com o meio urbano ou mesmo o restante do país.

Os baixos índices de acesso a água encanada, saneamento básico e a alta incidência de trabalho infantil e frequência escolar, bem como transições demográficas regionais díspares daquelas encontradas no ambiente urbano, ou mesmo de outras regiões rurais brasileira, como é o caso de uma base alargada da pirâmide etária e forte êxodo rural da população economicamente ativa, mostram o déficit social e demográfico que a região enfrenta.

Portanto, entende-se a necessidade de planejadores da política pública para o meio rural levarem em consideração os resultados aqui alcançados. Não se pode negar as especificadades de meios e condições de vida que as famílias da região amazônica detém. São pessoas em alta vulnerabilidade socioeconômica e que os gestores públicos devem estar atentos a essa mazelas, de forma que se consiga reverter tal cenário regional.

Essa radografia aqui apresentada é um bom começo para se pensar políticas focadas e direcionadas ao território amazônico, especialmente, nas regiões mais pobres, como é o caso da porção mais ocidental do Norte brasileiro. Serviços como educação, saúde e saneamento básico devem ser a prioriade, isto atrelado ao incentivo pela valorização do 
território rural e permanência das suas comunidades, evitando o êxodo de pessoas, que tem trazido graves problemas, em particular pelo inchaço nas comunidades urbanas dos municípios.

\section{Referências bibliográficas}

ARMELIN, M. J. C. Identificação e caracterização de áreas e comunidades com potencial para o desenvolvimento de sistemas comunitários de produção florestal no estado do Amapá. 2001. 131 f. Dissertação (Mestrado) Escola Superior de Agricultura "Luiz de Queiroz"/Universidade de São Paulo/Piracicaba. 2001.

BARROS, G. S. de C.; ZEN, S. de; BACCHI, M. R. P.; ICHIHARA, S. M.; OSAKI, M.; PONCHIO, L. A. Economia da pecuária de corte na Região Norte do Brasil. Centro de estudos avançados em economia aplicada ESALQ/USP. Piracicaba, agosto de $2002 . \quad$ Disponível <http://siteresources.worldbank.org/BRAZILINPOREXTN/Resources/3817166-1185895645304/4044168-

1185895685298/011_EconomiaPecuariaCorteRegNorte.pdf>. Acesso em: 26 nov. 2017.

BENTES, E. dos S.; AMIN, M. M. Influência do processo migratório no desenvolvimento sustentável da Amazônia. In: XLIII Congresso da Sociedade Brasileira de Economia, Administração e Sociologia Rural. Ribeirão Preto, 2005. Anais online. Disponível em: <http://www.sober.org.br/palestra/2/496.pdf>. Acesso em: 02 out. 2017.

BRASIL, Ministério da Integração Nacional. Ministério do Meio Ambiente. Plano Amazônia Sustentável - PAS: diagnóstico e estratégia. Volume 1. Brasília, abril de 2004.

BRASIL. Ministério da Integração Nacional. Política nacional de desenvolvimento regional. Brasília, agosto de 2005. Disponível em: <http://www.unc.br/mestrado/mestrado_materiais/10.03.08__PNDR_texto_prova_seletiva.pdf>. Acesso em: 27 dez. 2017.

CAMARANO, A. A.; ABRAMOVAY, R. Êxodo rural, envelhecimento e masculinização no Brasil: panorama dos últimos 50 anos. Brasília: IPEA, 1998. (Texto para Discussão no 621). Disponível em: <http://www.ipea.gov.br/portal/images/stories/PDFs/TDs/td_0621.pdf>. Acesso em: 03 out. 2017.

CARDOSO, F. H.; MÜLLER, G. A Amazônia de hoje. In: Amazônia: expansão do capitalismo [online]. Rio de Janeiro: Centro Edelstein de Pesquisas Sociais, 2008. p. 40 - 54.

COMISSÃO ECONÔMICA PARA A AMÉRICA LATINA E O CARIBE (CEPAL). Avaliação das políticas de desenvolvimento sustentável do estado do Acre (1999-2012). 2014. Disponível em: <http://repositorio.cepal.org/bitstream/handle/11362/37245/1/S1420296_pt.pdf>. Acesso em: 13 nov. 2017.

COMPANHIA NACIONAL DE ABASTECIMENTO (CONAB). Perspectivas para a agricultura. Brasília: CONAB, 2015.

COSTA, J. S. da; Cunha, M. da S. Determinantes do desemprego no Brasil no período de 1981 a 2005: uma análise enfatizando a qualificação do indivíduo em um contexto de maior abertura comercial. Análise Econômica, Porto Alegre, ano 28, n. 53, pp. 197-220, mar., 2010. Disponível em: <http://seer.ufrgs.br/index.php/AnaliseEconomica/article/view/8234/9662>. Acesso em: 29 set. 2017.

CUNHA, M. S. da; GAMES, P. C. Uma análise dos retornos salariais em escolaridade para o estado do Paraná de 1995 a 2009. Revista Paranaense de Desenvolvimento, Curitiba, v. 34, n. 124, pp. 157-174, jan./jun., 2013. Disponível em: <http://www.ipardes.pr.gov.br/ojs/index.php/revistaparanaense/article/view/468/818>. Acesso em: 29 set. 2017.

DANTAS, T. M.; FONTELES, L. V. Avanço da fronteira agrícola na Amazônia. Fundação Konrad Adenauer: Fortaleza, 2004.

Disponível

em: 
$<$ http://bvs1.panaftosa.org.br/local/file/textoc/avancos_fronteira_agricola_amazonia.pdf>. Acesso em: 28 out. 2017.

DIAS, J. C.; ARAÚJO, G. S. Informações estatísticas sobre o trabalho infantil na região Norte do Brasil a partir dos microdados do censo demográfico de 2010. Brasília: Contrato de Prestação de Serviço de Consultoria FNPETI. 2013. (Documento de Trabalho). Disponível em: $<$ http://www.fnpeti.org.br/arquivos/biblioteca/f8fof477f206c34dbb681d1a0cef7d8f.pdf>. Acesso em: 14 nov. 2017.

DOMINGUES. E. (Coord.) et al.. Cobertura e uso da terra no estado do Amapá. Rio de Janeiro: IBGE, Relatório Técnico, 2004. 137. Disponível em: <https://biblioteca.ibge.gov.br/visualizacao/livros/liv95893.pdfh>. Acesso em: 20 nov. 2017.

FREITAS, C. A. de; BACHA, C. J. C.; FOSSATI, D. M. Avaliação do desenvolvimento do setor agropecuário no Brasil: período de 1970 a 2000. Economia e Sociedade, v. 16, n. 1 (29), pp. 111-124, abr., 2007. Disponível em: <http://www.scielo.br/pdf/ecos/v16n1/a06v16n1.pdf>. Acesso em: 31 set. 2017.

GIL, A. C. Como elaborar projetos de pesquisa. 4ạ ed., 12으 reimpr., São Paulo: Atlas, 2009.

GODOY, A. S. Pesquisa qualitativas: tipos fundamentais. Revista de Administração de Empresas São Paulo, v. 35, n.3, p, 20-29 mai./jun., 1995. Disponível em: <http://www.scielo.br/pdf/rae/v35n3/a04v35n3.pdf>. Acesso em: 23 nov. 2017.

GUTBERLET, J. Zoneamento da Amazônia: uma visão crítica. Estudos Avançados. v.46, n. 16, 2002. Disponível em: <http://www.scielo.br/pdf/ea/v16n46/v16n46a13.pdf>. Acesso em: 28 set. 2017.

INSTITUTO BRASILEIRO DE GEOGRAFIA E ESTATÍSTICA (IBGE). Área territorial brasileira. Rio de Janeiro, 2017. Disponível em: <https://ww2.ibge.gov.br/home/geociencias/cartografia/default_territ_area.shtm>. Acesso em: 17 out. 2017.

INSTITUTO BRASILEIRO DE GEOGRAFIA E ESTATÍSTICA (IBGE). Mapas temáticos: densidade populacional 2010. Rio de Janeiro, 2010a. Disponível em: <ftp://geoftp.ibge.gov.br/cartas_e_mapas/mapas_do_brasil/sociedade_e_economia/mapas_murais/densidad e_populacional_2010.pdf>. Acesso em: 17 out. 2017.

INSTITUTO BRASILEIRO DE GEOGRAFIA E ESTATÍSTICA (IBGE). Grau de urbanização brasileira. Rio de Janeiro, 2010b. Disponível em: <https://seriesestatisticas.ibge.gov.br/series.aspx?vcodigo=pop119\#P1>. Acesso em: 17 out. 2017.

INSTITUTO BRASILEIRO DE GEOGRAFIA E ESTATÍSTICA (IBGE). Produto Interno Bruto dos municípios. Rio de Janeiro, 2010c. Disponível em: <https://sidra.ibge.gov.br/tabela/5938>. Acesso em: 26 jan. 2017.

INSTITUTO BRASILEIRO DE GEOGRAFIA E ESTATíSTICA (IBGE). Censo demográfico 2010. Rio de Janeiro, 2010d. Disponível em: <http://censo2010.ibge.gov.br/>. Acesso em: 25 jan. 2017.

INSTITUTO BRASILEIRO DE GEOGRAFIA E ESTATÍSTICA (IBGE). Estados. Rio de Janeiro, 2016. Disponível em: <http://www.ibge.gov.br/estadosat/>. Acesso em: 22 set. 2016.

INSTITUTO BRASILEIRO DE GEOGRAFIA E ESTATÍSTICA (IBGE). Projeto levantamento e classificação do uso da terra: estado do Pará. Rio de Janeiro: IBGE, Relatório técnico, junho de 2013. Disponível em: $<$ http://biblioteca.ibge.gov.br/visualizacao/livros/liv95892.pdf>. Acesso: 01 dez. 2017.

KRETER, A. C.; DEL-VECCHIO, R.; STADUTO, J. A. R. Condições habitacionais como um indicador de pobreza nas áreas rurais do Nordeste brasileiro. Rev. Econ. NE, Fortaleza, v. 46, n. 1, pp. 77-96, jan./mar., 2015. Disponível em: <https://ren.emnuvens.com.br/ren/article/view/181/159>. Acesso em: 29 set. 2017.

LEMOS, A. L. F.; SILVA, J. de A. Desmatamento na Amazônia Legal: evolução, causas, monitoramento e possibilidades de mitigação através do Fundo Amazônia. Floresta e Ambiente, vol. 1, n. 18, pp. 98-108, 2011. Disponível em: <http://www.floram.org/files/v18n1/v18n1a11.pdf>. Acesso em: 25 out. 2017.

MATOS, R. Migração e urbanização no Brasil. Geografias. 08 (1), jan./jun., p. 07-23, 2012. Disponível em: <igc.ufmg.br/portaldeperiodicos/index.php/geografias/article/download/557/427>. Acesso em: 30 set. 2017. 
MOURA, H. A.; MOREIRA, M de M. A população da região Norte: processos de ocupação e de urbanização recentes. Parcerias Estratégicas. Número 12, setembro de 2001 . Disponível em: <http://seer.cgee.org.br/index.php/parcerias_estrategicas/article/view/185>. Acesso em: 30 set. 2017.

OLIVEIRA, L. A. P. de. Os processos recentes de ocupação, expansão e a preocupação das fronteiras" In: MOURA, H. A.de. A pesquisa social na Amazônia: avanços, lacunas e prioridades. Recife: Massangana, 1996.

SECRETARIA DE PLANEJAMENTO, GOVERNANÇA E GESTÃO (SEPLAG). Departamento de Planejamento Governamental (DEPLAN). Taxa de Crescimento anual da população 2000-2010. Rio Grande do Sul, 2013. Disponível em: <http://www.atlassocioeconomico.rs.gov.br/midia/imagem/mapa-taxa-crescimento-brasil2000-2010>. Acesso em: 17 out. 2017.

SEVERINO, A. J. Metodologia do trabalho científico. 23a ed. revista e atualizada, 2a reimpr., São Paulo: Cortez, 2007.

SILVA, S. B. de M. e; SILVA, B. C. N. Roraima: problemas de desenvolvimento sustentável em uma região de fronteira. In: II Seminário Internacional sobre Desenvolvimento Regional, Santa Cruz do Sul, 2004. Anais online. Disponível em: <http://www.unisc.br/site/sidr/2004/sustentabilidade/18.pdf>. Acesso: 13 dez. 2017.

SOUSA, W. P. de. A dinâmica dos sistemas de produção praticados em uma Unidade de Conservação de uso direto na Amazônia: a reserva extrativista do Rio Cajari no estado do Amapá. 2006. 167 p. Dissertação (Mestrado em Agriculturas Amazônicas) Universidade Federal do Pará/Embrapa Amazônia Oriental, Belém, 2006.

SOUZA, M. M. O. de; PESSÔA, V. L. S. A contra-reforma agrária em Rondônia: colonização agrícola, expropriação e violência. In: V Encontro de Grupos de Pesquisas, UFSM/Santa Maria/RS, 2009. Anais online. Disponível em: <http://w3.ufsm.br/gpet/engrup/vengrup/anais/1/Murilo\%20Mendonca_NEAT-UFU.pdf>. Acesso em: 11 dez. 2017. 